\title{
Phytotherapeutic medicines: reality or myth?
}

\author{
Ceci Mendes Carvalho Lopes ${ }^{1}$ \\ Sônia Maria Rolim Rosa Lima² \\ (D) Eduardo C. de Arruda Veiga' \\ (iD) José Maria Soares-Jr' \\ Edmund Chada Baracat ${ }^{1}$
}

\begin{abstract}
1. Department of Endocrine Gynecology and Menopause, Discipline of Gynecology and Obstetrics, Hospital das Clínicas, Faculty of Medicine of the University of São Paulo; São Paulo, Brasil 2. Department of Gynecology and Obstetrics of the Faculty of Medical Sciences of the Santa Casa of São Paulo; São Paulo, Brasil
\end{abstract}

http://dx.doi.org/10.1590/1806-9282.65.3.292

Over the past decades, there has been an increase in medical professionals' interest in the use and knowledge of plant-based medications - phytotherapeutic medicines. This increased interest can be due to the possible risks of the irrational use of allopathic medicines, in addition to their high costs. The World Health Organization, since the Declaration of Alma-Ata (1978), acknowledges that around 85\% of the population of developing countries uses plants or plant-based products in healthcare. Therefore, it is necessary to respect and value this approach.

Phytotherapy is recognized as a therapeutic process encouraged by the national health bodies, but not as a medical specialty. There is no resolution on the subject by the Federal Council of Medicine. The Regional Council of Ceará recommends careful State supervision of its use as treatment by doctors. It is worth pointing out that, in its general concept, it is considered complementary treatment, like acupuncture and homeopathy. With this regard, the misinformation on the subject is clear, since the procedure to register phytotherapeutic medicines follows the same precepts and rules of any synthetic drug.

To avoid confusion on the subject, in 2012, legislation with a classification of three categories of plant-based products went into effect: plant drug (for teas); phytotherapic (finished product of living pharmacies) and phytotherapeutic medication. Considering the date of publication, we can observe that up to that point there was much confusion about the concept of phytotherapeutic medication, which was then defined as a product obtained exclusively from plant-based raw materials, with constant quality and reproducibility; as well as the knowledge of its risks and effectiveness, characterized by ethnopharmacological studies, technical-scientific documentation in publications or clinical trials. They also follow the same Anvisa rules for synthetic drugs It is necessary to emphasize the differences between countries regarding legislation on phytotherapics. In the United States, plant-based products are considered "nutritional supplements" and are not under the jurisdiction of its regulatory agency, the strict FDA. However, in Brazil, phytotherapics can be considered drugs and are supervised by strict legislation, under Anvisa, despite the fact that the definition of phytotherapic includes any product used as therapeutic and of exclusively plant-based origin. This includes, therefore, teas and artisanal or home-made preparations.

In research that aimed to evaluate the opinion of health professionals on the use of phytotherapics in public health care of Basic Health Units, $60 \%$ reported having information only from popular culture. Only $20 \%$ obtained knowledge from journals. This offers a glimpse of the huge risk of misinformation, or inappropriate or even erroneous conclusions. The interviewees added that the government program was 
introduced without the professionals involved being consulted or trained.

When doctors in the Family Health Program of the city of Canoas (RS), a city that practically does not have a rural area, were approached, of the 31 doctors in exercise, 27 agreed to be interviewed. In their great majority, they were up to 30 years old, which indicates they have concluded their studies recently. Virtually all reported not only using plants in their personal care, but also recommending them to patients (avoiding the term "prescribe"), but also demonstrated that their knowledge on the subject came from their families, or even from the patients themselves. The practically unanimous report that "there is no knowledge based on evidence-based medicine" clearly evidences the lack of knowledge of the professionals on the content of the numerous studies published in national or international journals, as well as a lack of knowledge that could have been obtained in their academic programs. Thus, although there was recognition of the pharmacological action of plant-based products, it can be considered as resulting from the trust and faith of the patient, in many cases (although the word was not mentioned) a placebo effect.

This lack of knowledge does happen exclusively in Brazil. In fact, in a study conducted in Switzerland highlighted the growing interest in the use of alternative practices such as phytotherapy, homeopathy, and acupuncture, but these subjects were also not included in the academic curricula of the country. The study aimed to evaluate precisely the doctors' and medical students' interest in this inclusion. The conclusion was that the desire exists and that there should be informative programs so that students can know about the real efficacy, interactions, side effects and safety of these methods.

About the medical training in phytotherapy, a study presented in Congress highlights the need for a greater approach to the subject in medical schools, and that much of what the medical class knows comes from the propaganda of the pharmaceutical industry and not from university education, although there is a national program encouraging the use of complementary and integrative practices.

A doctorate study addressed the inclusion of phytotherapy in the curricula of Brazilian public universities. It analyzed the teaching of phytotherapy in 59 public universities: in faculties of medicine there were 42 references to the teaching of phytotherapy; in faculties of pharmacy, 36; and in nutrition programs, 40. However, when the mandatory status of the discipline was analyzed, in medical courses only one (Federal University of Mato Grosso do Sul) addressed the topic, and in 36 pharmacy programs, it was part of the curriculum. It is worth noting that students and professionals have shown interest in its use and knowledge, provided that it is well established in scientific evidence.

Another important point is the misconception that plant-based products do not bring risks and can be ingested indiscriminately. It should be noted that like any other medication, plant derivatives have adverse and toxic effects. Also, the long-term effect of many of them is unknown and, therefore, requires education, research, and appropriate use. It is recommended that this should be done under medical supervision. Also, many times there is the advantage of a much lower cost than that of other therapeutic agents.

In a national study, the author reports data on phytotherapy training initiatives in different locations. Among several, she mentions the program "Uso de Plantas Medicinais e Fitoterápicos" [Use of Medicinal Plants and Phytotherapics] for community health agents, of the Avasus unit of the Ministry of Health, active since 2010. We had the opportunity to access it and observed that its primary objective is to inform the public, get a better understanding of the use of plants in the communities, but not particularly of phytotherapics. The study also mentions the phytotherapy program for doctors that was promoted by the Ministry of Health but taught only in 2003, to 300 participants. And the course "objective of the study," sponsored by the municipal government of São Paulo for health professionals, with several classes, since 2010, including the classes of 2014 and 2015, with a total of 165 participants included. However, only 27 of these were physicians.

In the interviews conducted in this study, the participants reported difficulties in obtaining scientific knowledge about the theme and some confusion between scientific data and popular knowledge. The widespread idea that there is no scientific evidence in relation to plant-based products is proved to be false by running a simple check. For example, in the website of the American National Health Service, PubMed, internationally used as a reference, in a search for Glycinemax (soya), we found 25,127 references. Using the word "therapy" as a filter, 2,942 
studies returned. After searching for, we found respectively 3,991or 2,017 publications. For (balmmint), 2,625 or 931 papers were found. For (mint), 931 or 143 studies. For (passionfruit), 645 or 171 works. There are obviously plant extracts much studied, and others not so often mentioned. These data show that there are numerous researchers around the world interested in the subject. Not to mention, of course, the possibility of access to other search sources available.

On the other hand, the idea of prescribing phytotherapeutic medicine does not mean replacing traditional medicines but widening therapeutic possibilities, since these are medicines and, as such, approved by Anvisa.

Brazil has a program sponsored by the Ministry of Health - the National Plan of Complementary and Integrative Therapies (PNPIC) - which covers the recommendation of use, by the Health System (SUS), of several therapeutic processes, such as acupuncture, homeopathy, and others, among them, phytothera-

\section{REFERENCES}

1. Rosa C, Câmara SG, Béria JU-Representações e intenção de uso da fitoterapia na atenção básica à saúde. Programa de pós-graduação em Saúde Coletiva, Universidade Luterana do Brasil, Av Farroupilha, 8001, prédio 14, sala 228, Bairro São José. 92425-900 Canoas RS (caroliner2007@gmail. com)

2. Parecer CREMEC No 33/2008ww.portalmedico,org.br/pareceres/ crmce/2008/33_2008.htm

3. Relatório da reunião em Brasília Política Nacional de Plantas Medicinais e Fitoterápicos (PNPMF)http://farmacia.saude.pe.gov.br/sites/farmacia. saude.pe.gov.br/files/programa-nacional-plantas-medicinais-fitoterapicos-sem-marca.pdf

4. Bruning $M C R$, Mosegui GBG, Vianna $C M M-A$ utilização da fitoterapia e de plantas medicinais em unidades básicas de saúde nos municípios de Cascavel e Foz de Iguaçu - Paraná: a visão dos profissionais de saúde. www,scielo.br/pdf/csc/v17n10/17.pdf

5. Nicolao M, Täuber MG, Heusser P. How should complementary and alternative medicine be taught to medical students in Switzerland? A survey of medical experts and students. Med Teach. 2010 Jan;32(1):50-5

6. Costa YMN, Lopes RP, Sousa JL, Frota MRX, Terceiro HBA- Fitpterapia e a formação médica: como avançar?AnCongBrasMedFam Comunidade. Belem, 2013 Maio; 12:1117

7. Barreto BB- Fitoterapia como conteúdo nos cursos de graduação da área da saúde: importância para a formação profissional. Tese de doutorado, Universidade de Brasilia, Faculdade de Ciências da Saúde, Programa de pós-graduação em ciências da Saúde, 2015 py. However, what we have observed is that, despite 12 plants having been approved for use in medicines, the SUS professionals of the do not often have in-depth information about the scientific knowledge of these plants, and its popular uses, including those common in the area in which the SUS unit is located, and "Living Pharmacies", i.e., the use of medicinal plants cultivated are consequentially favored and used many times .We cannot fail to recognize that in some cities, the programs were very well developed, with a very insightful staff, among which Vitória and Curitiba are particularly noteworthy, in addition to others.

Thus, we consider it is quite clear that phytotherapics can be very useful as a full or complementary therapy for many clinical conditions, but it is necessary to provide more information to the medical class (in particular the actual inclusion of the subject in academic courses) as well as to the public so that they can trust in such a powerful tool. Phytotherapeutic medicines need to be understood as a medicine available, an additional option, which is not a placebo!

8. Marques LC- Entre o conhecimento popular e o científico. www.comciencia,br/dossies-1-72-/reportagens/fito/fito1.htm

9. Haraguchi LMM-A fitoterapia praticada por profissionais de saúde participantes do curso "Plantas Medicinais e Fitoterapia" realizado pela Secretaria Municipal do Verde e do Meio Ambiente de São Paulo (2014/2015). Dissertação apresentada à Universidade Federal de São Paulo - Escola Paulista de Medicina - Departamento de Medicina Preventiva. 2p18

10. Carbonel AAF, Simões RS, Girão JHC, Sasso GRDS, Bertoncini CRA, Sorpreso ICE, Soares Junior JM, Simões MJ, Baracat EC. Isoflavones in gynecology. Rev Assoc Med Bras (1992). 2018;64(6):560-564.

11. del Giorno C, Fonseca AM, Bagnoli VR, Assis JS, Soares JM Jr, Baracat EC. Effects of Trifolium pratense on the climacteric and sexual symptoms in postmenopause women. Rev Assoc Med Bras (1992). 2010;56(5):558-62.

12. Lima SMRR, Campaner AB, Auge APF. Isoflavones derived from Glycine $\max (\mathrm{L}$.) Merr. in the treatment of vaginal atrophy: A new frontier. Rev Assoc Med Bras (1992). 2017 ;63(9):727-728.

13. Kaari C, Haidar MA, Júnior JM, Nunes MG, Quadros LG, Kemp C, Stavale JN, Baracat EC. Randomized clinical trial comparing conjugated equine estrogens and isoflavones in postmenopausal women: a pilot study. Maturitas. 2006 Jan 10;53(1):49-58.

14. Han KK, Soares JM Jr, Haidar MA, de Lima GR, Baracat EC. Benefits of soy isoflavone therapeutic regimen on menopausal symptoms. Obstet Gynecol. 2002;99(3):389-94.

15. Accorsi-Neto A, Haidar M, Simões R, Simões M, Soares | Jr, Baracat E. Effects of isoflavones on the skin of postmenopausal women: a pilot study. Clinics (Sao Paulo). 2009;64(6):505-10. 